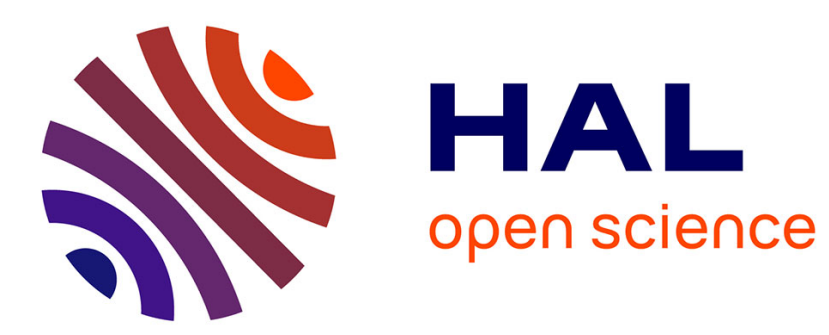

\title{
Education and household inequality change: a decomposition analysis for India
}

\author{
Janneke Pieters
}

\section{To cite this version:}

Janneke Pieters. Education and household inequality change: a decomposition analysis for India. The Journal of Development Studies, 2011, 47 (12), pp.1909-1924. 10.1080/00220388.2011.561323 . hal-00759558

\section{HAL Id: hal-00759558 https://hal.science/hal-00759558}

Submitted on 1 Dec 2012

HAL is a multi-disciplinary open access archive for the deposit and dissemination of scientific research documents, whether they are published or not. The documents may come from teaching and research institutions in France or abroad, or from public or private research centers.
L'archive ouverte pluridisciplinaire HAL, est destinée au dépôt et à la diffusion de documents scientifiques de niveau recherche, publiés ou non, émanant des établissements d'enseignement et de recherche français ou étrangers, des laboratoires publics ou privés. 


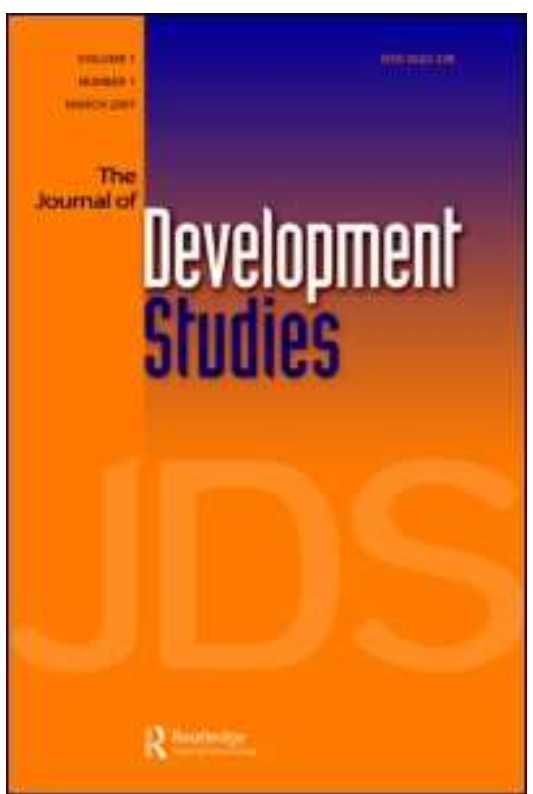

\section{Education and household inequality change: a decomposition analysis for India}

\begin{tabular}{|r|l|}
\hline Journal: & Journal of Development Studies \\
\hline Manuscript ID: & FJDS-2009-Dec-0031.R1 \\
\hline Manuscript Type: & Original Manuscripts \\
\hline Keywords: & $\begin{array}{l}\text { Economic development < Economics, Education < Education, South } \\
\text { Asia < Geographical Area, Development < Social Issues }\end{array}$ \\
\hline \multicolumn{2}{|c}{} \\
\hline
\end{tabular}

\section{SCHOLARONE \\ Manuscripts}




\begin{abstract}
Rising returns to education have increased wage inequality in many developing countries, but their impact on inequality between households is less clear. This study asks how education contributed to household inequality in India during the period 1993-2004, using a regression based decomposition method. We find that rising returns to education of employees did not increase household inequality, because many household heads are self-employed. Instead, rising inequality in education contributed to higher inequality, partly because fertility declined more slowly among illiterates. These new insights into the education-inequality relationship in India underline the importance of householdlevel analysis to complement earnings inequality research.
\end{abstract}

\title{
1. Introduction
}

Inequality is rising in many developing countries, but the determinants of changes in inequality are not well understood. There is abundant evidence from existing studies that education is a key aspect of earnings inequality dynamics in developed and developing countries (for example, Zhu and Trefler, 2005; Goldberg and Pavcnik, 2007). Due to skill-biased technical change and international trade demand for high-skilled labour is growing faster than supply, raising the returns to education.

But do rising returns to education also translate into higher household inequality? Households are more relevant from a welfare perspective than individuals: resources are, at least to some extent, shared among household members. As such, household inequality measures are more representative of a country's inequality situation and an important characteristic of the development process. ${ }^{1}$ Household income or expenditure inequality differs from individual earnings inequality in level as well as changes. For developing countries one may think of two main reasons why education is related differently to household inequality than to earnings inequality. 
First and foremost, besides earnings from employment, households have income from other sources. This is especially important in developing countries where about 60 per cent of workers are self-employed (ILO and WTO, 2009). These workers are not usually included in analyses of earnings inequality, so relatively little is known about their returns to education. Rising wage-returns to education tell us little about household inequality if a large part of household income is earned outside wage employment.

Second, education has indirect effects on income, for example through labour supply, occupational choices, and fertility decisions (Ram, 1989). These factors could leave the individual earnings distribution unaffected, but they matter for household inequality. For example, if higher education increases labour force participation of women, this will increase income of households with highly educated women. If these are relatively affluent households, household inequality will rise with educational expansion even if the earnings distribution is unchanged. A positive effect of education on an individual's earnings is thus only part of the effect on the household's well-being.

Compared to the many detailed studies on earnings, much less attention has been paid to changes in household inequality. Existing cross-country empirical evidence shows a weak relationship between education and household inequality (Ram, 1989; De Gregorio and Lee, 2002), which is not surprising given the multitude of factors that play a role. This paper focuses on the increase in household expenditure inequality in India between 1993-1994 and 2004-2005. India has experienced rapid growth since the economic reforms of the early 1990s and various analyses of the earnings distribution show that rising returns to education are the main cause for increased earnings inequality (for example, Kijima, 2006). India is an important case to study inequality beyond the distribution of earnings, since almost half of all households depend primarily on income from self-employment. Moreover, India has one of the most unequal education distributions in the world. Given the widespread attention to inequality of earnings due to education so far, it is important to ask how and how much education has actually contributed to household inequality. The main questions are whether rising wage returns to education have translated into higher household inequality, and how changes in educational attainment have affected inequality directly and through fertility changes. 
To answer these questions, the increase in household inequality in India is decomposed using household survey data and a regression-based method developed by Bourguignon et al. (2008). With this method it is possible to distinguish different channels through which education and other household or individual characteristics are related to household inequality. Like the standard OaxacaBlinder decomposition, it separates the distributional effect of changes in characteristics themselves versus changes in the returns to these characteristics. Rather than explaining differences in means between two distributions, however, the Bourguignon-method decomposed changes in the entire distribution. In contrast to other methods that compare full distributions (Juhn et al., 1993; DiNardo et al., 1996; Machado and Mata, 2005), this method focuses explicitly on the household income distribution, incorporating changes in, for example, household composition. As such, direct and indirect effects of education can be measured.

Our results show that declining returns to household head's education had an equalising effect in both rural and urban India. While returns to education among urban employees did rise, they declined in rural India and among urban self-employed household heads, reducing overall inequality. Changes in educational attainment had a strong inequality-increasing effect in rural India, due to the persistence of illiteracy. In addition, the indirect effect of education through fertility further increased rural inequality, because the increase in women's education and resulting decline in number of children was smaller in initially poorer households. The main conclusions are therefore that rising wage-returns to education of household heads have not translated into higher household inequality and that uneven increases in educational attainment levels contributed directly and indirectly to higher rural inequality. These new insights into the education-inequality relationship in India confirm the relevance of this type of analysis as a complement to research on individual earnings.

After describing inequality and other key characteristics of India in section 2, the decomposition method is discussed in section 3. Section 4 summarises estimation results that are part of the decomposition analysis, and in section 5 the final decomposition results are discussed.Section 6 concludes. 


\section{Inequality in India}

Data on household income is not available in India, so Indian inequality measures are based on consumption expenditure data, collected through nationally representative surveys by the National Sample Survey Organisation (NSSO). In a recent paper, Datt and Ravallion (2009: Table 2) show that consumption inequality in India increased significantly after major reforms started in 1991: the trend changed from negative to positive in rural India and from zero to positive in urban India. The present paper is based on survey data for 1993-1994 and 2004-2005. ${ }^{2}$

Table 1: Inequality of Monthly per Capita Expenditure

\begin{tabular}{lccccc}
\hline & \multicolumn{2}{c}{ Rural } & & \multicolumn{2}{c}{ Urban } \\
\cline { 2 - 3 } \cline { 5 - 6 } Year & Gini & Theil & & Gini & Theil \\
\hline 1993 & 29.4 & 18.0 & & 35.4 & 24.8 \\
2004 & 30.7 & 20.8 & & 37.4 & 28.1 \\
\hline
\end{tabular}

Note: Figures based on 17 major states plus urban Delhi.

Source: NSSO Consumer Expenditure survey

Table 1 shows the Gini coefficient and Theil index for inequality in monthly per capita expenditure $^{3}$ (henceforth $M P C E$ ) in these years: both measures show an increase in rural and urban inequality. Dhongde (2007) shows that, although growth reduced poverty in the 1980s and especially after the reforms in the 1990s, the increase in inequality in the post-reform period adversely affected the poor.

As opposed to household inequality, the distribution of earnings in India has been studied extensively. Chamarbagwala (2006) finds that during 1983-1999, relative demand shifted to more high-skilled workers especially in the service sector, causing a considerable increase in the wage gap between high- and low-educated workers. Dutta (2006) also finds evidence for a widening wage gap between graduate and primary education (for regular salaried employees), contributing to the rise in wage inequality in the 1990s. Kijima (2006) considers changes in both the returns to education and in educational attainment of male urban fulltime workers. She finds that during 1993-1999, earnings inequality increased due to rising returns to higher education caused by within-industry demand shifts. There seems to be no doubt that the wage gap between low- and high- skilled employees in India has grown, in line with the experience of many other countries. Due to data limitations, however, analyses 
Table 2: Educational attainment in India, percentage distribution

\begin{tabular}{|c|c|c|c|c|c|c|c|c|}
\hline \multirow[b]{3}{*}{ Education level } & \multicolumn{4}{|c|}{ Rural } & \multicolumn{4}{|c|}{ Urban } \\
\hline & \multicolumn{2}{|c|}{ Male } & \multicolumn{2}{|c|}{ Female } & \multicolumn{2}{|c|}{ Male } & \multicolumn{2}{|c|}{ Female } \\
\hline & 1993 & 2004 & 1993 & 2004 & 1993 & 2004 & 1993 & 2004 \\
\hline Illiterate & 45.85 & 35.03 & 75.54 & 63.82 & 17.91 & 13.25 & 40.10 & 31.03 \\
\hline Below primary & 14.68 & 9.62 & 7.91 & 6.53 & 10.86 & 6.22 & 9.93 & 6.69 \\
\hline Primary & 12.46 & 15.27 & 7.16 & 10.85 & 12.49 & 12.54 & 11.85 & 11.87 \\
\hline Middle & 12.32 & 18.62 & 5.23 & 10.08 & 15.91 & 19.45 & 12.23 & 15.91 \\
\hline Secondary & 11.66 & 16.93 & 3.55 & 7.29 & 26.73 & 29.53 & 16.60 & 21.52 \\
\hline Graduate or above & 3.04 & 4.52 & 0.61 & 1.45 & 16.10 & 19.02 & 9.28 & 12.99 \\
\hline Total & 100 & 100 & 100 & 100 & 100 & 100 & 100 & 100 \\
\hline
\end{tabular}

Note: Figures are based on all individuals of age 20 and higher. Source: NSSO Consumer Expenditure survey

As suggested by Ram (1989), the increased schooling of women may lead to a reduction in fertility. Education of women is generally negatively related to fertility, because desired family size declines and the ability to achieve the planned number of children improves with education. Between 1981 and 1991, women's education and child mortality were the most important factors explaining 
fertility differences across Indian states and over time (Drèze and Murthi, 2001). Since household expenditure is measured on a per capita basis and children typically do not generate income for the household, fewer children are associated with higher per capita expenditure. Changes in the average level and distribution of education among women could therefore affect household inequality indirectly through changes in fertility. The NSSO data show that during 1993-2004 there was a decline in the average number of children per household, especially in urban India (table 3). In both years, beyond the level 'Below primary', higher educational attainment of women is indeed associated with a lower number of children.

Table 3: Average number of children per household, by female education level

\begin{tabular}{lccccc}
\hline \multirow{2}{*}{$\begin{array}{l}\text { Average education level } \\
\text { females }\end{array}$} & \multicolumn{2}{c}{ Rural } & & \multicolumn{2}{c}{ Urban } \\
\cline { 2 - 3 } \cline { 5 - 6 } Illiterate & 1993 & 2004 & & 1993 & 2004 \\
Below primary & 2.04 & 2.03 & & 2.06 & 1.88 \\
Primary & 2.17 & 2.02 & & 1.92 & 1.91 \\
Middle & 1.99 & 1.80 & & 1.81 & 1.62 \\
Secondary & 1.79 & 1.64 & & 1.66 & 1.46 \\
Graduate and above & 1.60 & 1.45 & & 1.42 & 1.28 \\
Total & 1.23 & 1.09 & & 1.17 & 0.94 \\
\hline
\end{tabular}

Note: Children are household members of age 15 or younger. Educational level is the average of all adult females in the household. The total average includes households with no adult females. Source: NSSO Consumer Expenditure survey.

The following decomposition analysis will quantify how changes in returns to education, in educational attainment, and education-induced changes in fertility have contributed to household expenditure inequality in rural and urban India.

\section{Method and Application}

After discussing the decomposition framework and some India-specific considerations in section 3.1, the empirical strategy is explained in more detail in section 3.2

3.1 Decomposing changes in household inequality 
Bourguignon et al. (2005) and Bourguignon et al. (2008) develop a microeconometric decomposition of changes in the household income distribution that is designed to analyse household income inequality. The method is a generalization of the decomposition developed by Oaxaca (1973) and Blinder (1973), who separate inequality of mean income between groups into differences in characteristics, differences in returns to characteristics, and differences in unobserved factors. Using micro-economic data, the decomposition can be applied to the entire distribution of income, rather than their means. As opposed to decomposition methods of DiNardo et al. (1996) and Juhn et al. (1993), the level of analysis in the Bourguignon-method is the household rather than the individual, while individuals' characteristics are accounted for.

To decompose changes in inequality into endowment effects (the effect of changes in the distribution of household characteristics) and price effects (the effect of changes in the returns to these characteristics), distributional counterfactuals are constructed. Let $f^{t}(y)$ be the distribution of $M P C E$ in year t. $X$ is a vector of household characteristics and $\chi^{t}(X)$ is the joint distribution of all elements of $X$ in year $t$. Denoting $g^{t}(y \mid X)$, the distribution of income conditional on $X$, the marginal distribution of MPCE in year $t$ can be expressed as:

$$
f^{t}(y)=\int g^{t}(y \mid X) \chi^{t}(X) d X
$$

The change in the distribution of MPCE between two years is thus a function of the change in $g(y \mid X)$ (price effects) and the change in $\chi(X)$ (endowment effects).

The empirical equations are explained below, but for now note that expenditure of household $h$ in year $t, y_{h t}$, is a function of the vector $X_{h t}$ of household characteristics. Further, $y_{h t}$ depends on the vector $\beta_{t}$ of parameters reflecting the returns to those characteristics, on the vector $\varepsilon_{h t}$ of unobservable characteristics, the vector $\gamma_{t}$ of parameters reflecting educational attainment, and vector $\theta_{t}$ of parameters reflecting fertility choices.

$$
y_{h t}=F\left(X_{h t}, \beta_{t}, \varepsilon_{h t}, \gamma_{t}, \theta_{t}\right) .
$$

A change in household income, due to a change in one or some of the components of Eqn. 2, leads to a change in the distribution of income $f^{t}(y)$. The impact of each component can be simulated by 
replacing it by its counterpart of another year, say from year $t=0$ to $t=1$. For example, the vector $\beta_{0}$ can be replaced by $\beta_{1}$ while keeping everything else constant. This gives:

$$
y_{h 0}\left(\beta_{1}\right)=F\left(X_{h 0}, \beta_{1}, \varepsilon_{h 0}, \gamma_{0}, \theta_{0}\right) .
$$

The contribution of the change in $\beta$ to the total change in the income distribution (the so-called price effect) is then simply

$$
f_{\beta}^{0 \rightarrow 1}(y)-f^{0}(y)
$$

The same analogy applies to the other components of Eqn. 2. Since the entire distribution is simulated, the difference can be evaluated based on any measure of inequality.

Although the decomposition compares separate cross-sections, rather than following households within a panel dataset, the data requirements for this method are high. Ideally, one has individual earnings data and characteristics such as age and education, as well as household level non-earnings income and characteristics such as household size and composition. For India, there is no dataset combining individual level earnings and employment details with household level income. ${ }^{5}$ Due to these data restrictions, inequality and poverty analyses for India are always based on the consumer expenditure survey. This survey offers a reliable measure of welfare (Monthly Per Capita Expenditure: MPCE), but no individual employment and earnings details. ${ }^{6}$ Fortunately, the consumer expenditure survey does report individuals' level of educational attainment, age, and gender, and principal employment status, industry, and occupation of the household head.

A consequence of using the consumer expenditure survey is that individual earnings cannot be estimated. We therefore measure the 'returns to education' by the coefficients of education level dummies in a regression of per capita expenditure. For heads of households, who are mostly male and in the labour force, and for whom we control for employment status, industry, and occupation, this estimate will closely reflect the labour market returns to education. For other household members the estimates also measure the effect of education on, for example, labour force participation and hours worked. For completeness, the education level of the spouse and other household members is separately controlled for in the analysis, but the discussion is focused on the household head. 


$$
\ln \left(M P C E_{h t}\right)=X_{h t} \beta_{t}+\varepsilon_{h t}
$$

where the vector $X_{h t}$ is specified in Appendix table A.1. The OLS estimation results are available in table 1 of the online appendix to this article. The estimated coefficients in $\beta$ are used to calculate price effects.

Second, the educational attainment level is estimated by an ordered probit model, with six different levels of education: (1) Illiterate; (2) Literate below primary school; (3) Primary school; (4) Middle school; (5) Secondary or higher secondary education; and (6) Graduate and above. Educational attainment $x^{E}$ is estimated separately for the head, the spouse, and other members, and separately for rural and urban areas:

$$
\operatorname{Pr}\left[x_{i t}^{E}=k\right]=F\left(\alpha_{k, t}-X_{i t}^{-E F} \gamma_{t}\right)-F\left(\alpha_{k-1, t}-X_{i t}^{-E F} \gamma_{t}\right)
$$

where $i$ is the individual, $k(=1, \ldots, 6)$ is the highest education level completed, and $F$ is the standard normal cumulative distribution function. The cut-off values $\alpha_{k t}$ are estimated along with the regression parameters $\gamma_{t}$. The vector $X_{i t}^{-E F}$ includes gender, age (in linear splines), social group, religion, and state. Number of children is not included in this vector because education is itself an explanatory variable in the model for number of children. The estimated cut-off values in $\alpha$ and coefficients in $\gamma$ are used to simulate educational attainment and calculate the endowment effects of education.

For the number of children, $x^{F}$, an ordered probit model is estimated at the household level, separately for rural and urban areas:

$$
\operatorname{Pr}\left[x_{h t}^{F}=m\right]=F\left(\alpha_{m, t}-X_{h t}^{-F} \theta_{t}\right)-F\left(\alpha_{m-1, t}-X_{h t}^{-F} \theta_{t}\right),
$$


Where the number of children $m=1, \ldots, 12$ and $F$ is again the standard normal cumulative distribution function. The vector $X_{h t}^{-F}$ includes gender and age of the head, number of adult females, average age of adult females in linear splines, average education of adult females, social group, religion, and state. Since the data do not allow us to identify which children belong to which mother, age and education are averaged over all adult females (20 years or older) in the household. The estimated cut-off values in $\alpha$ and coefficients in $\theta$ are used to simulate changes in the number of children in order to calculate the indirect endowment effect of women's education.

Next, to obtain the price effect of education, a counterfactual distribution is constructed using 1993-94 as the base year $t=0$, and 2004-05 as year $t=1$. For each year, the vector of coefficients $\hat{\beta}$ in Eqn. 5 is estimated, and residuals are stored in $\hat{\varepsilon}$. Next, in the base-year vector $\hat{\beta}_{0}$, the coefficients for all education dummies are replaced by their counterparts from the end-year vector $\hat{\beta}_{1}$. The resulting vector is $\hat{\beta}_{\text {sim }}$. Finally, the value of MPCE is simulated for each household using base-year characteristics and unobservables: $\ln \left(M P C E_{h, s i m}\right)=X_{h 0} \hat{\beta}_{\text {sim }}+\hat{\varepsilon}_{h 0}$. The distribution of simulated $M P C E$ is the so-called counterfactual distribution. The difference between the base-year distribution and the counterfactual distribution is the contribution of the price effect of education. The price effects of other variables are calculated as well, in order to assess the relative importance of education.

To find the endowment effect of education on the expenditure distribution, a counterfactual distribution is obtained by changing educational attainment in $X_{h t}$ in Eqn. 5. The educational attainment of individuals in the base-year sample is 'updated' by simulation, based on the distribution of education conditional on individual characteristics. First, after estimating Eqn. 6, the base-year vector of characteristics $X_{i 0}{ }^{-E F}$ is multiplied by the end-year coefficient vector $\hat{\gamma}_{1}$. Combined with the end-year cut-off values $\hat{\alpha}_{k, 1}$, a simulated level of education is obtained for each individual. The simulated level of educational attainment replaces the original value in the base-year vector of characteristics $X_{h 0}$, which becomes $X_{h, s i m}$. A simulated value of MPCE for each household is obtained using base-year returns to characteristics and unobservables: $\ln \left(M P C E_{h, s i m}\right)=X_{h . s i m} \hat{\beta}_{0}+\hat{\varepsilon}_{h 0}$. 


\section{Estimation Results}

Before turning to the decomposition results in section 5, the estimation results of the three empirical equations are presented. For the consumption equation, the discussion is focused on the returns to education of the household head, in section 4.1. Then the results for education level and fertility estimation are briefly described in section 4.2 .

\subsection{Returns to Education}

Returns to education of the household head are estimated in the regression of household per capita expenditure, as described in Section 3. Figure 1 plots the coefficient estimates for five education level dummies (illiterate is the reference category) in rural and urban India in 1993 and 2004. Both rural and urban returns to education declined during this period: differences in expenditure between households with high- and low-educated heads narrowed. As opposed to existing evidence that returns to education have increased for employees, our estimation results suggest they have not increased among all rural or urban heads of households. This is a first indication that returns to education of household heads have not contributed to greater household inequality. 
Figure 1: Returns to education of household head

(a) Rural

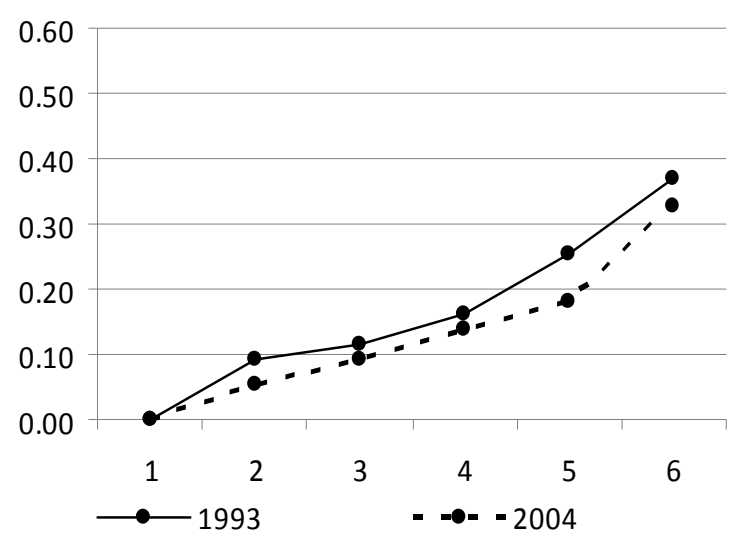

(b) Urban

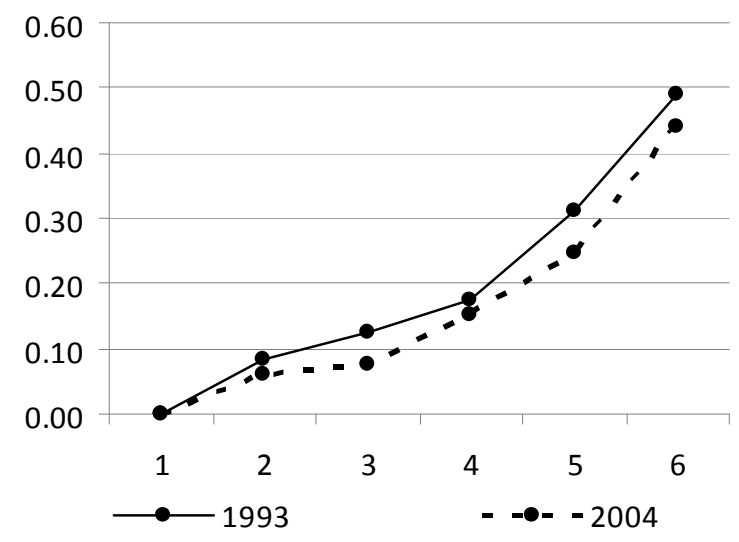

Source: NSSO Consumer Expenditure survey and author's calculations.

\subsection{Education and fertility}

The models for education and fertility in this analysis are used to obtain information on their conditional distributions, to be able to simulate endowment changes. Because education and number of children are explanatory variables in the $M P C E$ equation, consumption expenditure itself is not included as explanatory variable in either the education or the fertility model. For this reason, these models cannot be regarded as proper economic models (see Bourguignon et al. (2005) for more discussion). Nevertheless, a short discussion of the estimation results is appropriate.

In total, 12 ordered probit models of educational attainment are estimated: one for each year for rural and urban India, and for the head, spouse, and other household members separately. The results for household head and spouse are summarised in the online appendix tables 2 and 3. All results show that females have lower education than males, as do individuals belonging to a backward social group (scheduled caste or tribe), though the disadvantage of scheduled caste members declined between 1993 and 2004. Also, Muslims have on average lower education than Hindus, while Christians and other non-Hindus have significantly higher education levels.

The results for number of children are summarised in the online appendix table 4 . These show that higher education of women is associated with fewer children in the household. At higher levels of 
education the negative relationship is stronger. This could indicate that as female education levels rise, average fertility rates will fall more at higher levels of education, which could increase inequality.

\section{Decomposition Results}

In the decomposition analysis the price effects of all characteristics and the endowment effect of education (with and without the indirect effect through changes in the number of children) are simulated. An important note here is that the total change in the distribution cannot be decomposed additively into the changes of the components in Eqn. 2. Still, the size and direction of the price and endowment effects can be compared to one another and to the total change in inequality, in order to determine the relative importance of each.

Another issue is that the results depend on which year is chosen as base-year. The base-year determines, for example, at which distribution of characteristics $\left(X_{h}\right)$ the price effect (the change in $\beta$ ) is evaluated. For the price effect,

$$
f_{\beta}^{0 \rightarrow 1}(y)-f^{0}(y) \neq f^{1}(y)-f_{\beta}^{1 \rightarrow 0}(y)
$$

which applies to all components. In other words, the contribution to inequality made by one specific component is sensitive to the order in which the components are analysed, which is a problem of path dependency. We therefore report results for two decomposition paths and their average. ${ }^{7}$ The first path uses 1993 as base-year, measuring the contribution of each component when it is first in the decomposition path. The second path uses 2004 as base-year, measuring the contribution of each component when it is last in the decomposition path. The distributions are summarised using the Gini coefficient, but the log deviation and Theil index give very similar results.

The first three rows in table 4 show expenditure inequality in 1993 and 2004 and its absolute change. The remaining rows show the difference in inequality between counterfactual and base-year distribution. 
Table 4: Decomposition of inequality change 1993-2004

\begin{tabular}{|c|c|c|c|c|c|c|}
\hline & \multicolumn{3}{|c|}{ Rural } & \multicolumn{3}{|c|}{ Urban } \\
\hline & Path 1 & Path 2 & Average & Path 1 & Path 2 & Average \\
\hline Gini 1993 & 29.4 & 29.4 & 29.4 & 35.4 & 35.4 & 35.4 \\
\hline Gini 2004 & 30.7 & 30.7 & 30.7 & 37.4 & 37.4 & 37.4 \\
\hline Total change & 1.3 & 1.3 & 1.3 & 2.0 & 2.0 & 2.0 \\
\hline \multicolumn{7}{|l|}{ Price effects } \\
\hline Total & 0.4 & 0.4 & 0.4 & 0.8 & 1.4 & 1.1 \\
\hline Age & 0.1 & 0.1 & 0.1 & -0.1 & 0.1 & 0.0 \\
\hline Education all & -0.3 & -0.4 & -0.4 & 0.4 & 0.7 & 0.5 \\
\hline __head & -0.3 & -0.4 & -0.4 & -0.5 & -0.5 & -0.5 \\
\hline __spouse & 0.0 & 0.1 & 0.0 & 0.8 & 1.0 & 0.9 \\
\hline __others & 0.0 & 0.0 & 0.0 & 0.0 & 0.1 & 0.1 \\
\hline Children & 0.0 & 0.0 & 0.0 & -0.1 & -0.1 & -0.1 \\
\hline Household size & 0.0 & 0.0 & 0.0 & -0.1 & -0.1 & -0.1 \\
\hline Social group & 0.1 & 0.1 & 0.1 & 0.1 & 0.1 & 0.1 \\
\hline Religion & 0.0 & 0.1 & 0.1 & 0.0 & 0.0 & 0.0 \\
\hline Status & 0.2 & 0.2 & 0.2 & 0.1 & 0.2 & 0.2 \\
\hline Occupation & 0.2 & 0.2 & 0.2 & 0.1 & 0.1 & 0.1 \\
\hline Industry & -0.2 & -0.3 & -0.2 & 0.2 & 0.2 & 0.2 \\
\hline State & 0.3 & 0.4 & 0.4 & -0.3 & -0.1 & -0.2 \\
\hline \multicolumn{7}{|l|}{ Endowment effects } \\
\hline Education all & 0.2 & 0.4 & 0.3 & -0.3 & 0.4 & 0.1 \\
\hline _ head & 0.1 & 0.1 & 0.1 & -0.3 & 0.0 & -0.1 \\
\hline _ spouse & 0.2 & 0.2 & 0.2 & 0.1 & 0.4 & 0.3 \\
\hline _ others & 0.1 & 0.0 & 0.0 & 0.0 & 0.0 & 0.0 \\
\hline Educ. all + children & 0.5 & 0.4 & 0.4 & -0.3 & 0.1 & -0.1 \\
\hline
\end{tabular}

Note: 1993 is base-year in Path 1, 2004 is base-year in Path 2. Source: Author's calculations based on NSSO Consumer Expenditure survey.

All price effects combined ("Total") account for almost one third of the total increase in rural inequality and more than half of the increase in urban inequality. However, the price effect of education of the household head is negative. That is, changing returns to household heads' education contributed to a decline of household inequality in both rural and urban India, a result that is further discussed below. The total of all price effects is positive due to price effects of other characteristics, notably location (state) of the household in rural India, and education of the spouse in urban India.

The endowment effect of education ("Education all") is positive in both rural and urban India, which means changes in education levels account for an increase in inequality. ${ }^{8}$ The effect on urban inequality is small, but for rural inequality it is almost as large as all price effects combined. To better understand the endowment effect, a mobility matrix is constructed comparing base-year and simulated education levels. The simulation shows the education level a person from the 1993-sample would have 
if he or she were in the 2004-sample (or the other way around, depending on the choice of base-year), given his or her age, gender, social group, religion, and location. An example is given below in table 5 for the education of spouses in rural India. As this matrix shows, most progress in terms of educational attainment is made by individuals who are literate and completed up to middle school (levels 2, 3, and 4). This pattern appears in all simulations; for rural and urban heads, spouses, and other members.

\begin{tabular}{lrrrrrrr}
\multicolumn{7}{l}{ Table 5: Simulated education mobility matrix, spouses in rural India } \\
\hline $\begin{array}{l}\text { Simulated level 2004 } \\
\text { Education 1993 }\end{array}$ & 1 & 2 & 3 & 4 & 5 & 6 & Total \\
\hline 1 - Illiterate & 86.3 & 8.5 & 5.1 & 0 & 0 & 0 & 100 \\
2 - Below primary & 0.1 & 6.1 & 79.9 & 13.9 & 0 & 0 & 100 \\
3 - Primary & 0 & 0 & 15.5 & 79.9 & 4.6 & 0 & 100 \\
4 - Middle & 0 & 0 & 0 & 30.4 & 69.6 & 0 & 100 \\
5 - Secondary & 0 & 0 & 0 & 0 & 76.0 & 24.0 & 100 \\
6 - Graduate and higher & 0 & 0 & 0 & 0 & 0 & 100 & 100 \\
\hline
\end{tabular}

Source: NSSO Consumer Expenditure survey and author's calculations.

On average, relatively little progress is made by the group of illiterates, which explains why the direct endowment effect of education was inequality-increasing. The distributional impact shows up most clearly in rural India and for spouses, as the share of illiterates is largest in rural India and among women. These results illustrate the scope for improvement in the distribution of education and household expenditure, by focusing more on expanding schooling for the lowest class.

Finally, the effect of changes in the number of children (due to changes in women's education) is added to the direct endowment effect of education, which is shown in the bottom row of table 4 ("Educ. all + children"). The indirect effect increases rural inequality further, but is equalising in urban India. Among rural households, those with higher initial expenditure level have a higher increase in the average female education level. Consequently, the decline in the number of children is larger for initially richer households, which is why inequality rises. In urban India, average female education increases most in the bottom half of the initial expenditure distribution. Among urban households, therefore, the number of children declines more in households with lower initial expenditure, reducing inequality. 
All in all, the price effect of education is equalising in rural India, while the endowment effect of education accounts for a large part of the increase in inequality. Changing educational attainment has a direct and indirect effect on rural inequality, by 'leaving behind' the illiterates, who then also have smaller reductions in fertility. The price effect of education contributes to higher inequality in urban India, due to education of spouses, while the endowment effect is close to zero. Given the existing evidence for increasing returns to education among employees, the equalising price effect of household head's education in both rural and urban India warrants further discussion.

\subsection{Returns to education: employees versus self-employed household heads}

Although several studies have shown that earnings inequality increased in the 1990s due to rising returns to education, our results suggest that with respect to household consumption expenditure, differences attributable to household heads' education have actually narrowed. As discussed in the introduction, this may reflect the relationship between education and other sources of income. In particular, 40 tot 50 per cent of the household heads is self-employed, but little is known about their returns to education, because no income or earnings data are available for this group.

To test whether self-employment income drives our results, the decomposition analysis has been repeated separately for "employee" and "non-employee" households. For urban employee households (head is a regular or casual employee) the price effect of the head's education is indeed positive, so rising returns to education have increased inequality among these household. However, the effect is strongly negative for the non-employee households (head is self-employed or other), among which inequality associated with the head's education level declined. Since this decline is relatively large, the overall price effect of the head's education is equalising in urban India.

In rural India the price effect is negative for both employee and non-employee households. Regarding previous earnings studies, Kijima (2006) analyses only male urban fulltime workers, and studies that include both rural and urban workers do not estimate the returns to education for each group separately (Chamarbagwala, 2006; Dutta, 2006). Since their samples are dominated by male urban workers, these are likely to drive the results, and it is unclear how wage-returns to education 


\section{Summary and conclusions}

From the large body of research on earnings inequality we know that rising returns to education have led to higher earnings inequality in many countries, including developing countries. For household inequality, however, the role of education is less clear. In this paper we examine the relationship between education and household inequality dynamics in India over the period 19932004. A microeconometric decomposition of inequality changes shows the distributive effects of changes in returns to education, changes in educational attainment, and the indirect effect of the latter through fertility.

The decomposition results indicate that changes in the returns to education of household heads reduced rural and urban household expenditure inequality. This finding is important given that previous research has shown that the main cause for higher earnings inequality after 1993 is an increase in the returns to education (Chamarbagwala, 2006; Dutta, 2006; Kijima, 2006). We find that our results are different because we include self-employed household heads in our sample: the returns to education of the head only increase inequality among urban employee-headed-households, while they decline for non-employee-headed urban households and rural households. Taking into account non-employees thus appears to be crucial when studying the link between education and household inequality change.

Contrary to the household head, the returns to spouse's education increased urban inequality. Since the data we use contain no employment or earnings details for spouses, and their labour force participation rate is rather low, it is hard to interpret this finding at present. More research is needed to understand the role of women's returns to education in household inequality dynamics.

The final main result is that changes in educational attainment increased rural inequality. Other studies have found that a distribution-neutral increase in average educational attainment can increase inequality (see Bourguignon et al., 2005) due to the convex relationship between education and 
earnings. The present study of India shows a more alarming picture, namely, that rising educational attainment increased household inequality because the inequality of education itself increased. The simulation results indicate that educational attainment is only slowly improving for the large group of illiterate adults, and much faster for literates with some education. This also increases inequality indirectly, through fertility reductions. The impact on urban inequality is almost zero, because the share of illiterate adults is lower in urban India. Still, urban educational expansion is unequal as well, and there is much scope for improvement in rural and urban India alike. To reduce household consumption inequality, and inequality of education itself, stimulating literacy is essential.

In general, this study shows that household-level inequality analysis provides new insights in addition to the abundant existing results from the earnings literature. Research on individual earnings inequality, therefore, needs to be complemented by further analysis at the household level to gain deeper insight into the dynamics of education and inequality. Especially the returns to education outside wage-employment and the role of women's education are important topics for further research.

\section{Notes}

${ }^{1}$ For a discussion, see Atkinson and Bourguignon (2000: 34).

${ }^{2}$ Henceforth 1993 and 2004. These 'thick' survey rounds use the same reference period, whereas the survey in 1999-2000 used mixed reference periods. It is by now well-established that this affected measures of poverty and inequality, so the 1999-2000 measures are not comparable (see Deaton and Drèze, 2002).

${ }^{3}$ In constant prices and spatially deflated, based on the price indexes by Deaton (2003) for 1987-1999 and the official Consumer Price Index for Agricultural Labour and Consumer Price Index for Industrial Workers for 1999-2004. Deaton's indexes are more carefully calculated than the official national price indexes, but are only available at the state level until 1999.

${ }^{4}$ Based on a survey of street vendors in Delhi in 1995, Dasgupta (2003) shows there is no relationship between earnings and education among these self-employed workers.

${ }^{5}$ The National Sample Survey on employment and unemployment (the usual source of earnings data in India) does not record earnings for self-employed workers or total household income.

${ }^{6}$ Until 1993-94 the employment and the consumer expenditure survey were collected from the same sample of households. For more recent years, the surveys are taken from two separate samples. Per capita expenditure is now recorded in the employment survey based on a limited list of items: the resulting expenditure measure in 2004-05 is not comparable to the 1993-94 measure or to the consumer expenditure survey in 2004-05. The employment survey can therefore not be used for analyses of expenditure inequality dynamics.

${ }^{7}$ Devicienti (2009) shows that each component's Shapley-value can be calculated as the average of its contribution to inequality across all possible decomposition paths. However, since we look at 
educational attainment of the household head, spouse, and other members separately, as well as the indirect fertility effect, the number of different possible decomposition paths is large, and calculating the Shapley-value would be a cumbersome exercise. Results are therefore reported for the two "extreme" decompositions paths and their average.

${ }^{8}$ The urban results are quite different between the two decomposition paths: this is due to differences in prices at which the endowment changes are evaluated, and differences in the distribution of other household characteristics. 


\section{References}

Atkinson, A. B. and Bourguignon, F. (2000) Introduction: Income distribution and economics, in: Atkinson, A. B. and Bourguignon, F. (eds) Handbook of Income Distribution 1, (Amsterdam: North Holland), pp. 1-58.

Blinder, A. S. (1973) Wage discrimination: Reduced form and structural estimates. Journal of Human Resources, 8(4), pp. 436-455.

Bourguignon, F., Ferreira, F. H. G., and Leite, P. G. (2008) Beyond Oaxaca-Blinder: Accounting for differences in household income distributions. Journal of Economic Inequality, 6, pp. 117-148.

Bourguignon, F., Ferreira, F. H. G., and Lustig, N. E. (eds.) (2005) The Microeconomics of Income Distribution Dynamics (Washington, DC: World Bank and Oxford University Press).

Chamarbagwala, R. (2006) Economic liberalization and wage inequality in India. World Development, 34(12), pp. 1997-2015.

Dasugpta, S. (2003) Structural and behavioural characteristics of informal service employment: evidence from a survey in New Delhi. Journal of Development Studies, 39(3), pp. 51-80.

Datt, D. and Ravallion, M. (2009) Has India's economic growth become more pro-poor in the wake of economic reforms? Policy Research Working Paper 5103, World Bank, Washington D.C.

De Gregorio, J. and Lee, J. W. (2002) Education and income inequality: new evidence from crosscountry data. Review of Income and Wealth, 48(3), pp. 395-416.

Deaton, A. (2003) Prices and poverty in India, 1987-2000. Economic and Political Weekly, 38, pp. $362-368$.

Deaton, A. and Drèze, J. (2002) Poverty and inequality in India: a re-examination. Economic and Political Weekly, 7, pp. 3729-3748.

Devicienti, F. (2009) Shapley-value decompositions of changes in wage distributions: a note. Journal of Economic Inequality, Article in Press. DOI: 10.1007/s10888-008-9102-3.

Dhongde, S. (2007) Measuring the impact of growth and income distribution on poverty in India. Journal of Income Distribution, 16(2), pp. 25-48. 
DiNardo, J., Fortin, N. M.,and Lemieux, T. (1996) Labour market institutions and the distribution of wages, 1973-1992: a semiparametric approach. Econometrica, 64(5), pp. 1001-1044.

Drèze, J. and Murthi, M. (2001) Fertility, education, and development: evidence from India. Population and Development Review, 27(1), pp. 33-63.

Dutta, P. V. (2006). Returns to education: New evidence for India, 1983-1999. Education Economics, 14, pp. 431-451.

Goldberg, P. K. and Pavcnik, N. (2007) Distributional effects of globalization in developing countries. Journal of Economic Literature, 45(1), pp. 39-82.

Government of India (2008). Eleventh five year plan (2007-2012) Technical report, Planning Commission, New Delhi.

International Labour Organization and World Trade Organization (2009) Globalization and informal jobs in developing countries (Geneva: ILO and WTO).

Juhn, C., Murphy, K. M., and Pierce, B. (1993) Wage inequality and the rise in return to skill. Journal of Political Economy, 101, pp. 410-442.

Kijima, Y. (2006) Why did wage inequality increase? Evidence from urban India 1983-99. Journal of Development Economics, 81(1), pp. 97-117.

Kochhar, K., Kumar, U., Rajan, R., Subramanian, A., and Tokatlidis, I. (2006) India's pattern of development: what happened, what follows? Journal of Monetary Economics, 53(5), pp. 981-1019.

Machado, J. A. F. and Mata, J. (2005) Counterfactual decomposition of changes in wage distributions using quantile regression. Journal of Applied Econometrics, 20(4), pp. 445-465.

Mazumdar, D. and Sarkar, S. (2008) Globalization, Labour Markets and Inequality in India (New York: Routeledge).

Oaxaca, R. (1973) Male-female wage differentials in urban labour markets. International Economic Review, 14(3), pp. 693-709.

Ram, R. (1989) Can educational expansion reduce income inequality in less-developed countries? Economics of Education Review, 8(2), pp. 185-195. 
Zhu, S. C. and Trefler, D. (2005) Trade and inequality in developing countries: a general equilibrium analysis. Journal of International Economics, 65(1), pp. 21-48.

\section{Appendix}

Table A.1: List of explanatory variables in MPCE regression equation

\begin{tabular}{ll}
\hline Variable & Description \\
\hline Age_head & Age of household head \\
Age_head_sq & Squared age of household head \\
Age_other & Average age other members \\
Age_other_sq & Squared average age other members \\
Female_head & Indicator variable for female head of household \\
Educh & Indicator variables for education level of household head \\
Educs & Indicator variables for education level of spouse \\
Educo & Indicator variables for average education level other members \\
Nchild & Number of children (age 0-15) \\
N16_19 & Number of teenagers (age 16-19) \\
Nmale20_65 & Number of male adults \\
Nfem20_65 & Number of female adults \\
N65 & Number of elderly \\
Social group & Indicator variables for scheduled caste, scheduled tribe, or other* \\
Religion & Indicator variables for Hindu*, Muslim, Christian, or other religion \\
Status & Indicator variable for principal employment status: self-employed*, casual \\
Occupation & labour, salaried labour, or other. \\
Industry & Indicator variable for principal occupation : professional, administrative, or \\
State & other* \\
Subround & Indicator variable for principal industry: ten industries \\
Note: * indicates reference category in $M P C E$ regression equation. For education the reference category is \\
illiterate. For industry the reference category is agriculture. Casual and salaried labour is one category in the \\
rural sample. & Indicator variable for State \\
& Indicator variable for survey subround
\end{tabular}


Education and household inequality change: a decomposition analysis for India

\section{Online Appendix}

Table 1: Household MPCE estimation results

\begin{tabular}{|c|c|c|c|c|}
\hline \multirow{2}{*}{$\begin{array}{l}\text { Dependent variable is } \ln (M P C E) \\
\text { Variable }\end{array}$} & \multicolumn{2}{|c|}{ Rural } & \multicolumn{2}{|c|}{ Urban } \\
\hline & 1993 & 2004 & 1993 & 2004 \\
\hline Age_head & $\begin{array}{l}0.006^{* * * *} \\
(0.001)\end{array}$ & $\begin{array}{l}0.005^{* * *} \\
(0.001)\end{array}$ & $\begin{array}{l}0.007 * * * \\
(0.002)\end{array}$ & $\begin{array}{l}0.008^{* * *} \\
(0.002)\end{array}$ \\
\hline Age_head_sq & $\begin{array}{l}-0.000 * * * \\
(0.000)\end{array}$ & $\begin{array}{l}-0.000 * * * \\
(0.000)\end{array}$ & $\begin{array}{l}-0.000 * * * \\
(0.000)\end{array}$ & $\begin{array}{l}-0.000 * * \\
(0.000)\end{array}$ \\
\hline Age_other & $\begin{array}{l}0.004 * * * \\
(0.001)\end{array}$ & $\begin{array}{l}0.003 * * * \\
(0.001)\end{array}$ & $\begin{array}{l}-0.005^{* * * *} \\
(0.001)\end{array}$ & $\begin{array}{l}0.000 \\
(0.002)\end{array}$ \\
\hline Age_other_sq & $\begin{array}{l}-0.000 * * * \\
(0.000)\end{array}$ & $\begin{array}{l}-0.000 \text { **** } \\
(0.000)\end{array}$ & $\begin{array}{l}0.000 * * * \\
(0.000)\end{array}$ & $\begin{array}{l}0.000 \\
(0.000)\end{array}$ \\
\hline Female_head & $\begin{array}{l}-0.082 * * * \\
(0.012)\end{array}$ & $\begin{array}{l}-0.076^{* * * *} \\
(0.014)\end{array}$ & $\begin{array}{l}-0.144 * * * \\
(0.016)\end{array}$ & $\begin{array}{l}-0.159 * * * \\
(0.022)\end{array}$ \\
\hline Educh_2 & $\begin{array}{l}0.091 * * * \\
(0.006)\end{array}$ & $\begin{array}{l}0.053^{* * * *} \\
(0.008)\end{array}$ & $\begin{array}{l}0.085^{* * * *} \\
(0.010)\end{array}$ & $\begin{array}{l}0.061 * * * \\
(0.017)\end{array}$ \\
\hline Educh_3 & $\begin{array}{l}0.116 * * * \\
(0.007)\end{array}$ & $\begin{array}{l}0.091 * * * \\
(0.007)\end{array}$ & $\begin{array}{l}0.125^{* * * *} \\
(0.011)\end{array}$ & $\begin{array}{l}0.075^{* * *} \\
(0.013)\end{array}$ \\
\hline Educh_4 & $\begin{array}{l}0.160 * * * \\
(0.008)\end{array}$ & $\begin{array}{l}0.139 * * * \\
(0.007)\end{array}$ & $\begin{array}{l}0.173 * * * \\
(0.011)\end{array}$ & $\begin{array}{l}0.149 * * * \\
(0.013)\end{array}$ \\
\hline Educh_5 & $\begin{array}{l}0.254 * * * \\
(0.010)\end{array}$ & $\begin{array}{l}0.187 * * * \\
(0.009)\end{array}$ & $\begin{array}{l}0.311 * * * \\
(0.012)\end{array}$ & $\begin{array}{l}0.257 * * * \\
(0.015)\end{array}$ \\
\hline Educh_6 & $\begin{array}{l}0.369 * * * \\
(0.019)\end{array}$ & $\begin{array}{l}0.321 * * * \\
(0.020)\end{array}$ & $\begin{array}{l}0.490 * * * \\
(0.016)\end{array}$ & $\begin{array}{l}0.434 * * * \\
(0.021)\end{array}$ \\
\hline Educs_O & $\begin{array}{l}0.165^{* * * *} \\
(0.009)\end{array}$ & $\begin{array}{l}0.165^{* * *} \\
(0.012)\end{array}$ & $\begin{array}{l}0.240 * * * \\
(0.014)\end{array}$ & $\begin{array}{l}0.304 * * * \\
(0.019)\end{array}$ \\
\hline Educs_2 & $\begin{array}{l}0.051 * * * \\
(0.008)\end{array}$ & $\begin{array}{l}0.059 * * * \\
(0.009)\end{array}$ & $\begin{array}{l}0.045 * * * \\
(0.012)\end{array}$ & $\begin{array}{l}0.045^{* * *} \\
(0.017)\end{array}$ \\
\hline Educs_3 & $\begin{array}{l}0.060 * * * \\
(0.009)\end{array}$ & $\begin{array}{l}0.048 * * * \\
(0.009)\end{array}$ & $\begin{array}{l}0.035^{* * * *} \\
(0.011)\end{array}$ & $\begin{array}{l}0.056 * * * \\
(0.013)\end{array}$ \\
\hline Educs_4 & $\begin{array}{l}0.106 * * * \\
(0.012)\end{array}$ & $\begin{array}{l}0.091 * * * \\
(0.009)\end{array}$ & $\begin{array}{l}0.063 * * * \\
(0.011)\end{array}$ & $\begin{array}{l}0.097 * * * \\
(0.015)\end{array}$ \\
\hline Educs_5 & $\begin{array}{l}0.157 * * * \\
(0.022)\end{array}$ & $\begin{array}{l}0.176 * * * \\
(0.015)\end{array}$ & $\begin{array}{l}0.172 * * * \\
(0.013)\end{array}$ & $\begin{array}{l}0.219 * * * \\
(0.016)\end{array}$ \\
\hline Educs_6 & $\begin{array}{l}0.319 * * * \\
(0.049)\end{array}$ & $\begin{array}{l}0.396 * * * \\
(0.038)\end{array}$ & $\begin{array}{l}0.325 * * * \\
(0.018)\end{array}$ & $\begin{array}{l}0.465^{* * * *} \\
(0.023)\end{array}$ \\
\hline Educo_o & $\begin{array}{l}0.139 * * * \\
(0.007)\end{array}$ & $\begin{array}{l}0.157 * * * \\
(0.008)\end{array}$ & $\begin{array}{l}0.145 * * * \\
(0.013)\end{array}$ & $\begin{array}{l}0.211^{* * * *} \\
(0.018)\end{array}$ \\
\hline Educo_2 & $\begin{array}{l}0.051 * * * \\
(0.008)\end{array}$ & $\begin{array}{l}0.032 * * * \\
(0.011)\end{array}$ & $\begin{array}{l}0.017 \\
(0.016)\end{array}$ & $\begin{array}{l}0.077 * * * \\
(0.024)\end{array}$ \\
\hline Educo_3 & $\begin{array}{l}0.084 * * * \\
(0.009)\end{array}$ & $\begin{array}{l}0.057 * * * \\
(0.010)\end{array}$ & $\begin{array}{l}0.044 * * * * \\
(0.016)\end{array}$ & $\begin{array}{l}0.054 * * * \\
(0.020)\end{array}$ \\
\hline Educo_4 & $\begin{array}{l}0.139 * * * \\
(0.011)\end{array}$ & $\begin{array}{l}0.090 * * * \\
(0.010)\end{array}$ & $\begin{array}{l}0.077 * * * \\
(0.015)\end{array}$ & $\begin{array}{l}0.080 * * * \\
(0.020)\end{array}$ \\
\hline
\end{tabular}

URL: http://mc.manuscriptcentral.com/fjds 
Table 1 continued

\begin{tabular}{|c|c|c|c|c|}
\hline Educo_5 & $\begin{array}{l}0.171^{* * *} * \\
(0.011)\end{array}$ & $\begin{array}{l}0.162 * * * \\
(0.011)\end{array}$ & $\begin{array}{l}0.121 * * * \\
(0.015)\end{array}$ & $\begin{array}{l}0.146^{* * * *} \\
(0.019)\end{array}$ \\
\hline Educo_6 & $\begin{array}{l}0.245 * * * \\
(0.036)\end{array}$ & $\begin{array}{l}0.252^{* * * *} \\
(0.021)\end{array}$ & $\begin{array}{l}0.187 * * * \\
(0.018)\end{array}$ & $\begin{array}{l}0.237 * * * \\
(0.023)\end{array}$ \\
\hline NChild & $-0.086 * * *$ & $-0.085^{* * *}$ & $-0.112 * * *$ & $-0.108 * * *$ \\
\hline N16_19 & $\begin{array}{l}-0.016 * * * \\
(0.003)\end{array}$ & $\begin{array}{l}-0.022 * * * \\
(0.004)\end{array}$ & $\begin{array}{l}-0.057 * * * \\
(0.005)\end{array}$ & $\begin{array}{l}-0.061 * * * \\
(0.006)\end{array}$ \\
\hline Nmale20_65 & $\begin{array}{l}0.014 * * * \\
(0.004)\end{array}$ & $\begin{array}{l}0.008^{* *} \\
(0.004)\end{array}$ & $\begin{array}{l}-0.007 \\
(0.005)\end{array}$ & $\begin{array}{l}-0.009 \\
(0.007)\end{array}$ \\
\hline Nfemale20_65 & $\begin{array}{l}-0.006 \\
(0.004)\end{array}$ & $\begin{array}{l}-0.004 \\
(0.005)\end{array}$ & $\begin{array}{l}-0.034 * * * \\
(0.006)\end{array}$ & $\begin{array}{l}-0.031 * * * \\
(0.008)\end{array}$ \\
\hline N65 & $\begin{array}{l}0.006 \\
(0.007)\end{array}$ & $\begin{array}{l}0.022 * * * \\
(0.008)\end{array}$ & $\begin{array}{l}-0.023 * * \\
(0.011)\end{array}$ & $\begin{array}{l}-0.031 * * \\
(0.013)\end{array}$ \\
\hline$S C$ & $\begin{array}{l}-0.100 * * * \\
(0.005)\end{array}$ & $\begin{array}{l}-0.102 * * * \\
(0.006)\end{array}$ & $\begin{array}{l}-0.094 * * * \\
(0.010)\end{array}$ & $\begin{array}{l}-0.112 * * * \\
(0.011)\end{array}$ \\
\hline$S T$ (ref=other social group) & $\begin{array}{l}-0.139 * * * \\
(0.008)\end{array}$ & $\begin{array}{l}-0.165^{* * * *} \\
(0.008)\end{array}$ & $\begin{array}{l}-0.090^{* * * *} \\
(0.017)\end{array}$ & $\begin{array}{l}-0.095 * * * \\
(0.022)\end{array}$ \\
\hline Islam & $\begin{array}{l}-0.008 \\
(0.007)\end{array}$ & $\begin{array}{l}-0.008 \\
(0.008)\end{array}$ & $\begin{array}{l}-0.029 * * * \\
(0.009)\end{array}$ & $\begin{array}{l}-0.008 \\
(0.012)\end{array}$ \\
\hline Christian & $\begin{array}{l}-0.049 * * * \\
(0.015)\end{array}$ & $\begin{array}{l}0.063 * * * \\
(0.018)\end{array}$ & $\begin{array}{l}0.064 * * * \\
(0.018)\end{array}$ & $\begin{array}{l}0.037 * \\
(0.022)\end{array}$ \\
\hline Other religion $(\mathrm{ref}=\mathrm{Hindu})$ & $\begin{array}{l}0.050 * * * \\
(0.015)\end{array}$ & $\begin{array}{l}0.060 * * * \\
(0.018)\end{array}$ & $\begin{array}{l}0.035^{* *} \\
(0.016)\end{array}$ & $\begin{array}{l}0.146 * * * \\
(0.024)\end{array}$ \\
\hline Labour (rural) & $\begin{array}{l}-0.187 * * * \\
(0.005)\end{array}$ & $\begin{array}{l}-0.167 * * * \\
(0.005)\end{array}$ & & \\
\hline Salaried labour (urban) & & & $\begin{array}{l}0.022 * * * \\
(0.008)\end{array}$ & $\begin{array}{l}0.061 * * * \\
(0.010)\end{array}$ \\
\hline Casual labour (urban) & & & $\begin{array}{l}-0.202^{* * * *} \\
(0.010)\end{array}$ & $\begin{array}{l}-0.191 \text { *** } \\
(0.013)\end{array}$ \\
\hline Other status (ref=self-employed) & $\begin{array}{l}-0.013 \\
(0.011)\end{array}$ & $\begin{array}{l}0.071 \text { *** } \\
(0.015)\end{array}$ & $\begin{array}{l}0.015 \\
(0.019)\end{array}$ & $\begin{array}{l}-0.037 \\
(0.033)\end{array}$ \\
\hline Professional & $\begin{array}{l}-0.044 * * * \\
(0.013)\end{array}$ & $\begin{array}{l}0.032 \\
(0.021)\end{array}$ & $\begin{array}{l}0.073 * * * \\
(0.012)\end{array}$ & $\begin{array}{l}0.091 * * * \\
(0.019)\end{array}$ \\
\hline Administrative (ref=other) & $\begin{array}{l}0.084 * * * \\
(0.023)\end{array}$ & $\begin{array}{l}0.147 * * * \\
(0.023)\end{array}$ & $\begin{array}{l}0.217 * * * \\
(0.014)\end{array}$ & $\begin{array}{l}0.219^{* * * *} \\
(0.016)\end{array}$ \\
\hline Constant & $\begin{array}{l}5.854 * * * \\
(0.031)\end{array}$ & $\begin{array}{l}5.960 * * * \\
(0.037)\end{array}$ & $\begin{array}{l}5.747 * * * \\
(0.046)\end{array}$ & $\begin{array}{l}5.703 * * * \\
(0.061)\end{array}$ \\
\hline Observations & 58787 & 59162 & 37293 & 33279 \\
\hline R-squared & 0.331 & 0.391 & 0.489 & 0.517 \\
\hline
\end{tabular}

Note: Dependent variable is the log of household real monthly per capita expenditure. Estimation by OLS, standard errors in parentheses. Sig $* * * \mathrm{p}<0.01$, ** $\mathrm{p}<0.05, * \mathrm{p}<0.1$. All estimations include dummies for industry, state, and survey subround. Source: NSSO Consumer Expenditure survey. 
Table 2: Results ordered probit estimation for education, household head

\begin{tabular}{|c|c|c|c|c|}
\hline \multirow[b]{2}{*}{ Variable } & \multicolumn{2}{|c|}{ Rural, head } & \multicolumn{2}{|c|}{ Urban, head } \\
\hline & 1993 & 2004 & 1993 & 2004 \\
\hline Female & $\begin{array}{l}-0.881 * * * \\
(0.022)\end{array}$ & $\begin{array}{l}-0.912 * * * \\
(0.025)\end{array}$ & $\begin{array}{l}-0.737 * * * \\
(0.029)\end{array}$ & $\begin{array}{l}-0.903 * * * \\
(0.045)\end{array}$ \\
\hline Age 1 & $\begin{array}{l}-0.014 * * * \\
(0.004)\end{array}$ & $\begin{array}{l}0.006 \\
(0.005)\end{array}$ & $\begin{array}{l}-0.011^{*} \\
(0.006)\end{array}$ & $\begin{array}{l}0.045 * * * \\
(0.007)\end{array}$ \\
\hline Age2 & $\begin{array}{l}0.014 * * * \\
(0.006)\end{array}$ & $\begin{array}{l}-0.025 * * * \\
(0.007)\end{array}$ & $\begin{array}{l}0.023 * * * \\
(0.008)\end{array}$ & $\begin{array}{l}-0.052 * * * \\
(0.010)\end{array}$ \\
\hline Age3 & $\begin{array}{l}-0.031 * * * \\
(0.004)\end{array}$ & $\begin{array}{l}0.008 * \\
(0.004)\end{array}$ & $\begin{array}{l}-0.034 * * * \\
(0.005)\end{array}$ & $\begin{array}{l}0.015 * * \\
(0.007)\end{array}$ \\
\hline Age4 & $\begin{array}{l}0.014 * * * \\
(0.003)\end{array}$ & $\begin{array}{l}-0.013 * * * \\
(0.003)\end{array}$ & $\begin{array}{l}0.008 * * \\
(0.007)\end{array}$ & $\begin{array}{l}-0.031 * * * \\
(0.005)\end{array}$ \\
\hline $\mathrm{SC}$ & $\begin{array}{l}-0.614 * * * \\
(0.015)\end{array}$ & $\begin{array}{l}-0.515 * * * \\
(0.016)\end{array}$ & $\begin{array}{l}-0.868 * * * \\
(0.025)\end{array}$ & $\begin{array}{l}-0.694 * * * \\
(0.027)\end{array}$ \\
\hline ST & $\begin{array}{l}-0.705^{* * * *} \\
(0.020)\end{array}$ & $\begin{array}{l}-0.747 * * * \\
(0.024)\end{array}$ & $\begin{array}{l}-0.589 * * * \\
(0.049)\end{array}$ & $\begin{array}{l}-0.620 * * * \\
(0.056)\end{array}$ \\
\hline Islam & $\begin{array}{l}-0.500 * * * \\
(0.020)\end{array}$ & $\begin{array}{l}-0.449 * * * \\
(0.021)\end{array}$ & $\begin{array}{l}-0.709 * * * \\
(0.023)\end{array}$ & $\begin{array}{l}-0.726^{* * * *} \\
(0.029)\end{array}$ \\
\hline Christian & $\begin{array}{l}0.246 * * * \\
(0.037)\end{array}$ & $\begin{array}{l}0.153 * * * \\
(0.039)\end{array}$ & $\begin{array}{l}0.352 * * * \\
(0.042)\end{array}$ & $\begin{array}{l}0.256 * * * \\
(0.053)\end{array}$ \\
\hline Other non-Hindu & $\begin{array}{l}0.102 * * \\
(0.044)\end{array}$ & $\begin{array}{l}0.162 * * * \\
(0.047)\end{array}$ & $\begin{array}{l}0.233 * * * \\
(0.041)\end{array}$ & $\begin{array}{l}0.315 * * * \\
(0.052)\end{array}$ \\
\hline Cut-off values & & & & \\
\hline 1 & $\begin{array}{l}-0.583 * * * \\
(0.051)\end{array}$ & $\begin{array}{l}-0.856 * * * \\
(0.067)\end{array}$ & $\begin{array}{l}-1.186 * * * \\
(0.069)\end{array}$ & $\begin{array}{l}-0.865^{* * * *} \\
(0.074)\end{array}$ \\
\hline 2 & $\begin{array}{l}-0.127 * * \\
(0.051)\end{array}$ & $\begin{array}{l}-0.547 * * * \\
(0.067)\end{array}$ & $\begin{array}{l}-0.777 * * * \\
(0.069)\end{array}$ & $\begin{array}{l}-0.576^{* * * *} \\
(0.075)\end{array}$ \\
\hline 3 & $\begin{array}{l}0.293 * * * \\
(0.051)\end{array}$ & $\begin{array}{l}-0.102 \\
(0.067)\end{array}$ & $\begin{array}{l}-0.408 * * * \\
(0.069)\end{array}$ & $\begin{array}{l}-0.148 * * \\
(0.075)\end{array}$ \\
\hline 4 & $\begin{array}{l}0.774 * * * \\
(0.051)\end{array}$ & $\begin{array}{l}0.456 * * * \\
(0.067)\end{array}$ & $\begin{array}{l}-0.003 \\
(0.069)\end{array}$ & $\begin{array}{l}0.357 * * * \\
(0.074)\end{array}$ \\
\hline 5 & $\begin{array}{l}1.563 * * * \\
(0.052)\end{array}$ & $\begin{array}{l}1.331^{* * * *} \\
(0.070)\end{array}$ & $\begin{array}{l}0.786 * * * \\
(0.069)\end{array}$ & $\begin{array}{l}1.177 * * * \\
(0.075)\end{array}$ \\
\hline $\begin{array}{l}\text { Observations } \\
\text { Pseudo R2 }\end{array}$ & $\begin{array}{l}58787 \\
0.06\end{array}$ & $\begin{array}{l}59162 \\
0.05\end{array}$ & $\begin{array}{l}37293 \\
0.05\end{array}$ & $\begin{array}{l}33279 \\
0.05\end{array}$ \\
\hline
\end{tabular}

Note: All estimations include state dummies. Standard errors are in parentheses. Sig $* * * \mathrm{p}<0.01, * *$ $\mathrm{p}<0.05,{ }^{*} \mathrm{p}<0.1$.Age is measured in linear splines (marginal) 20-30, 30-40, and 40-50, 50+. Source: NSSO Consumer Expenditure survey. 
Table 3: Results ordered probit estimation for education, spouse

\begin{tabular}{|c|c|c|c|c|}
\hline \multirow[b]{2}{*}{ Variable } & \multicolumn{2}{|c|}{ Rural } & \multicolumn{2}{|c|}{ Urban } \\
\hline & 1993 & 2004 & 1993 & 2004 \\
\hline \multirow[t]{2}{*}{ Female } & $-0.441 * * *$ & $-0.574 * * *$ & $-0.489 * * *$ & $-0.371 * *$ \\
\hline & $(0.142)$ & $(0.148)$ & $(0.175)$ & $(0.187)$ \\
\hline \multirow[t]{2}{*}{ Age 1 } & $-0.009 * *$ & $-0.029 * * *$ & $0.019 * * *$ & $0.016^{* *}$ \\
\hline & $(0.003)$ & $(0.004)$ & $(0.004)$ & $(0.007)$ \\
\hline \multirow[t]{2}{*}{ Age2 } & $-0.012 * *$ & -0.002 & $-0.032 * * *$ & $-0.031 * * *$ \\
\hline & $(0.005)$ & $(0.006)$ & $(0.007)$ & $(0.010)$ \\
\hline \multirow[t]{2}{*}{ Age3 } & $-0.014 * * *$ & 0.002 & $-0.014 * *$ & 0.003 \\
\hline & $(0.005)$ & $(0.005)$ & $(0.006)$ & $(0.008)$ \\
\hline \multirow[t]{2}{*}{ Age4 } & $0.019 * * *$ & 0.002 & $0.011 * *$ & $-0.018 * *$ \\
\hline & $(0.005)$ & $(0.005)$ & $(0.006)$ & $(0.008)$ \\
\hline \multirow[t]{2}{*}{ SC } & $-0.675^{* * *}$ & $-0.617 * * *$ & $-1.042 * * *$ & $-0.855 * * *$ \\
\hline & $(0.021)$ & $(0.020)$ & $(0.030)$ & $(0.033)$ \\
\hline \multirow[t]{2}{*}{ ST } & $-0.748 * * *$ & $-0.886^{* * *}$ & $-0.742 * * *$ & $-0.766^{* * * *}$ \\
\hline & $(0.031)$ & $(0.030)$ & $(0.066)$ & $(0.072)$ \\
\hline \multirow[t]{2}{*}{ Islam } & $-0.437 * * *$ & $-0.501 * * *$ & $-0.769 * * *$ & $-0.696 * * *$ \\
\hline & $(0.028)$ & $(0.025)$ & $(0.026)$ & $(0.031)$ \\
\hline \multirow[t]{2}{*}{ Christian } & $0.392 * * *$ & $0.269 * * *$ & $0.447 * * *$ & $0.387 * * *$ \\
\hline & $(0.045)$ & $(0.044)$ & $(0.047)$ & $(0.054)$ \\
\hline \multirow[t]{2}{*}{ Other non-Hindu } & $0.191 * * *$ & $0.404 * * *$ & $0.340 * * *$ & $0.509 * * *$ \\
\hline & $(0.057)$ & $(0.059)$ & $(0.044)$ & $(0.053)$ \\
\hline \multicolumn{5}{|l|}{ Cut-off values } \\
\hline \multirow[t]{2}{*}{1} & 0.155 & $-0.904 * * *$ & $-0.881 * * *$ & $-1.049 * * *$ \\
\hline & $(0.156)$ & $(0.174)$ & $(0.188)$ & $(0.202)$ \\
\hline \multirow[t]{2}{*}{2} & $0.525^{* * *}$ & $-0.655^{* * *}$ & $-0.588 * * *$ & $-0.830 * * *$ \\
\hline & $(0.156)$ & $(0.174)$ & $(0.188)$ & $(0.202)$ \\
\hline \multirow[t]{2}{*}{3} & $1.003^{* * *}$ & -0.162 & -0.208 & $-0.459 * *$ \\
\hline & $(0.156)$ & $(0.174)$ & $(0.188)$ & $(0.202)$ \\
\hline \multirow[t]{2}{*}{4} & $1.541 * * *$ & $0.447 * *$ & 0.216 & 0.027 \\
\hline & $(0.156)$ & $(0.175)$ & $(0.188)$ & $(0.202)$ \\
\hline \multirow[t]{2}{*}{5} & $2.417 * * *$ & $1.377 * * *$ & $0.976^{* * *}$ & $0.854 * * *$ \\
\hline & $(0.159)$ & $(0.182)$ & $(0.188)$ & $(0.202)$ \\
\hline Observations & 48516 & 50565 & 28652 & 26769 \\
\hline Pseudo R2 & 0.11 & 0.10 & 0.06 & 0.05 \\
\hline
\end{tabular}

Note: All estimations include state dummies. Standard errors are in parentheses. Sig *** $\mathrm{p}<0.01, * *$ $\mathrm{p}<0.05, * \mathrm{p}<0.1$. Age is measured in marginal linear splines 20-30, 30-40, and 40-50, 50+.

Source: NSSO Consumer Expenditure survey. 
Table 4: Results ordered probit estimation for household average number of children

\begin{tabular}{|c|c|c|c|c|c|c|c|c|c|c|c|}
\hline \multirow[b]{2}{*}{ Variable } & \multicolumn{2}{|c|}{ 1993, rural } & \multicolumn{3}{|c|}{2004 , rural } & \multicolumn{3}{|c|}{ 1993, urban } & \multicolumn{3}{|c|}{ 2004, urban } \\
\hline & Coef. & Std. & Coef. & Std. & & Coef. & Std. & & Coef. & Std. & \\
\hline Female head & -0.378 & $0.018 * * *$ & -0.247 & 0.023 & $* * *$ & -0.367 & 0.028 & $* * *$ & -0.232 & 0.038 & $* * *$ \\
\hline Age head & -0.002 & $0.000 * * *$ & -0.001 & 0.001 & $* *$ & -0.003 & 0.001 & $* * *$ & -0.005 & 0.001 & $* * *$ \\
\hline $\mathrm{N}$ females & 1.010 & $0.030 * * *$ & 1.251 & 0.040 & $* * *$ & 0.985 & 0.052 & $* * *$ & 1.070 & 0.070 & $* * *$ \\
\hline Age1 & 0.237 & $0.004 * * *$ & 0.274 & 0.005 & $* * *$ & 0.279 & 0.007 & $* * *$ & 0.270 & 0.010 & $* * *$ \\
\hline Age2 & -0.315 & $0.008 * * *$ & -0.389 & 0.010 & $* * *$ & -0.381 & 0.013 & $* * *$ & -0.401 & 0.016 & $* * *$ \\
\hline Age3 & -0.113 & $0.014 * * *$ & -0.101 & 0.017 & $* * *$ & -0.107 & 0.023 & $* * *$ & -0.070 & 0.024 & $* * *$ \\
\hline females*age 1 & -0.108 & $0.004 * * *$ & -0.141 & 0.005 & $* * *$ & -0.137 & 0.007 & $* * *$ & -0.137 & 0.008 & $* * *$ \\
\hline females*age2 & 0.130 & $0.007 * * *$ & 0.184 & 0.008 & $* * *$ & 0.175 & 0.010 & $* * *$ & 0.188 & 0.013 & $* * *$ \\
\hline females*age3 & 0.071 & $0.013 * * *$ & 0.061 & 0.015 & $* * *$ & 0.057 & 0.021 & $* * *$ & 0.031 & 0.020 & \\
\hline Educf_0 & 0.238 & $0.041 * * *$ & 0.468 & 0.062 & $* * *$ & -0.605 & 0.065 & $* * *$ & -0.660 & 0.129 & $* * *$ \\
\hline Educf_2 & -0.042 & $0.016 * * *$ & -0.120 & 0.019 & $* * *$ & -0.093 & 0.027 & $* * *$ & -0.044 & 0.040 & \\
\hline Educf_3 & -0.146 & $0.019 * * *$ & -0.241 & 0.017 & $* * *$ & -0.194 & 0.024 & $* * *$ & -0.239 & 0.033 & $* * *$ \\
\hline Educf_4 & -0.254 & $0.026 * * *$ & -0.323 & 0.020 & $* * *$ & -0.334 & 0.025 & $* * *$ & -0.374 & 0.033 & $* * *$ \\
\hline Educf_5 & -0.362 & $0.032 * * *$ & -0.463 & 0.026 & $* * *$ & -0.509 & 0.024 & $* * *$ & -0.509 & 0.034 & $* * *$ \\
\hline Educf_6 & -0.653 & $0.084 * * *$ & -0.714 & 0.073 & $* * *$ & -0.800 & 0.031 & $* * *$ & -0.829 & 0.039 & $* * *$ \\
\hline $\mathrm{SC}$ & -0.010 & 0.013 & 0.071 & 0.015 & $* * *$ & 0.133 & 0.024 & $* * *$ & 0.119 & 0.029 & $* * *$ \\
\hline ST & -0.056 & $0.017 * * *$ & 0.086 & 0.022 & $* * *$ & 0.024 & 0.042 & & 0.055 & 0.052 & \\
\hline Muslim & 0.336 & $0.019 * * *$ & 0.385 & 0.022 & $* * *$ & 0.409 & 0.025 & $* * *$ & 0.433 & 0.032 & $* * *$ \\
\hline Christian & 0.028 & 0.038 & 0.116 & 0.042 & $* * *$ & 0.109 & 0.040 & $* * *$ & 0.085 & 0.059 & \\
\hline Other & -0.015 & 0.036 & 0.011 & 0.045 & & 0.001 & 0.042 & & -0.017 & 0.053 & \\
\hline \multicolumn{12}{|l|}{ Cut-off values } \\
\hline 1 & 0.242 & 0.049 & 0.819 & 0.061 & & 0.398 & 0.082 & & 0.342 & 0.096 & \\
\hline 2 & 0.929 & 0.049 & 1.512 & 0.061 & & 1.117 & 0.083 & & 1.102 & 0.096 & \\
\hline 3 & 1.628 & 0.050 & 2.296 & 0.062 & & 1.885 & 0.083 & & 1.988 & 0.096 & \\
\hline 4 & 2.295 & 0.050 & 2.948 & 0.062 & & 2.611 & 0.084 & & 2.679 & 0.097 & \\
\hline 5 & 2.890 & 0.051 & 3.505 & 0.063 & & 3.197 & 0.084 & & 3.188 & 0.099 & \\
\hline 6 & 3.395 & 0.051 & 3.986 & 0.064 & & 3.681 & 0.086 & & 3.560 & 0.101 & \\
\hline 7 & 3.828 & 0.053 & 4.430 & 0.066 & & 4.114 & 0.089 & & 3.954 & 0.106 & \\
\hline 8 & 4.152 & 0.055 & 4.783 & 0.069 & & 4.474 & 0.095 & & 4.345 & 0.111 & \\
\hline 9 & 4.441 & 0.058 & 5.067 & 0.073 & & 4.709 & 0.104 & & 4.669 & 0.119 & \\
\hline 10 & 4.679 & 0.063 & 5.279 & 0.080 & & 4.799 & 0.110 & & 4.857 & 0.126 & \\
\hline 11 & 4.879 & 0.069 & 5.489 & 0.091 & & 4.980 & 0.129 & & 5.035 & 0.140 & \\
\hline 12 & 5.137 & 0.080 & 5.818 & 0.088 & & 5.136 & 0.149 & & 5.173 & 0.159 & \\
\hline $\mathrm{N}$ & 58787 & & 59162 & & & 37293 & & & 33279 & & \\
\hline pseudo R2 & 0.10 & & 0.12 & & & 0.15 & & & 0.15 & & \\
\hline
\end{tabular}

Note: All estimations include state dummies. Sig $* * * \mathrm{p}<0.01, * * \mathrm{p}<0.05$. Age is measured in linear splines (marginal) 20-30, 30-40, and 40+. Source: NSSO Consumer Expenditure survey. 